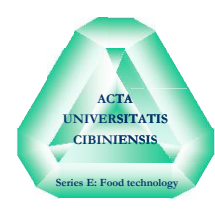

\title{
QUALITY PARAMETERS OF WHEAT
} BREAD ENRICHED WITH PUMPKIN
(CUCURBITA MOSCHATA) BY-PRODUCTS

\author{
Solvita KAMPUSE ${ }^{1}$, Liene OZOLA, \\ Evita STRAUMITE, Ruta GALOBURDA
}

Latvia University of Agriculture, Faculty of Food Technology

\begin{abstract}
Pumpkin processing into puree, juice, candied fruit and pumpkin seed oil results in large amount of by-products. Pumpkins are rich in carotenes, vitamins, minerals, pectin and dietary fibre. The aim of the current study was to evaluate effect of pumpkin pomace and pumpkin residue powder on wheat bread quality. The total content of carotenes was analyzed by spectrophotometric method. The initial increase of pumpkin residue addition indicated increase in loaf volume, which started to decrease at higher amounts. Sensory evaluation (appearance; surface, crust; porosity; texture, crumb; taste, and flavour) of wheat bread with pumpkin revealed very high consumer acceptance except sample with $50 \%$ pomace addition. Total carotene content and colour $\mathrm{b}^{*}$ value in wheat bread increased by adding pumpkin byproducts. It is recommended to add $5 \%$ and $10 \%$ of pumpkin powder and no more than $30 \%$ of pumpkin pomace (calculated per $100 \mathrm{~kg}$ of flour) to dough for production of wheat bread with pumpkin by-product additions.
\end{abstract}

Keywords: pumpkin by-products, pomace, total carotenoids, porosity, texture

\section{INTRODUCTION}

Pumpkin processing into puree, juice, candied fruit and pumpkin seed oil results in large amount of by-products. Pumpkins are rich in carotenoids, vitamins, minerals, pectin and dietary fibre. Noelia et al. (2011) conducted a review on Cucurbita moschata and reported that it constitutes an important source $(20 \pm 4 \mathrm{mg} / \mathrm{g})$ of vitamin A (González et al., 2001) and it is high in carotenoids, especially $\beta$-carotene and lutein, both of which are important nutritionally (González et al., 2001), (Noseworthy \& Loy, 2008). Carvalho, de et al. (2012) determined a mean total carotenoid content between $234.21 \mu \mathrm{g} / \mathrm{g}$ and $404.98 \mu \mathrm{g} / \mathrm{g}$ depending on landrace. Another study

\footnotetext{
${ }^{1}$ Corresponding author. Mailing address: Faculty of Food Technology, Liela Street 2, Jelgava, Latvia.E-mail: skampuse@inbox.lv
} 
evaluating twenty-two cultivars of C. moschata reported a total carotenoid content ranging from $7.02 \mu \mathrm{g} / \mathrm{g}$ to $138.56 \mu \mathrm{g} / \mathrm{g}$ (Azizah et al., 2009). Kandlakunta et al. (2008) reported total carotenoid content levels of $2120 \mu \mathrm{g} / 100 \mathrm{~g}$ and $\beta$-carotene $1180 \mu \mathrm{g} / 100 \mathrm{~g}$ in the yellow pumpkin (C. maxima).

It is suggested that a diet rich in carotenoids is associated with enhancement of the immune response and reduction of the risk of degenerative diseases such as cancer, cardiovascular diseases, atherosclerosis, cataracts, and agerelated macular degeneration via prevention of lipid peroxidation (González et al., 2001), (Noelia et al., 2011). The carotenoids act as free radical traps and thus may play an important role in cancer prevention (Lee et al., 2002). Furthermore, pumpkins contain polysaccharides, proteins and peptides, paraaminobenzoic acid, phenolic compounds, terpenoids and sterols (Kuhlmann et al., 1999). Thus pumpkin can be considered as a promising raw material for functional food product development.

Numerous studies have been conducted on wheat bread enrichment with various ingredients improving its nutritional value. However these additional ingredients may adversely affect sensory qualities of bread. Thus Coelho and Salas-Mellado (2015) reported that the technological quality of the loaves was affected by adding chia materials in the formulations, leading to a decrease in the specific volume and the total score values. Gailite et al. (2008) studied use of raspberry marc in wheat bread and concluded that adding 3\%, 5\%, and 7\% raspberry marc influenced the colour of bread crumb, aroma, flavour and sourness of the wheat bread differently but it does not influence its porosity. Another study demonstrates effect of Jerusalem artichoke powder (JAP) on wheat bread quality (Gedrovica and Karklina, 2011). Partial replacement of wheat flour with JAP at different levels $(10,20$, 30,40 , and $50 \%$ ) significantly changed the qualitative and quantitative thermo-mechanical properties of enriched dough. In the samples with JAP in concentration $50 \%$ and $100 \%$ was observed disintegration of the proteinchain under the mechanical-pressure force in Mixolab test.

Some earlier studies revealed that pumpkin incorporation in wheat bread would improve its nutritional value and quality characteristics (Ptitchkina et al., 1998), (Rakcejeva et al., 2011). There are only few studies on pumpkin by-product use in bread making. According to Ptitchkina et al.(1998) study pumpkin powder, introduced in wheat bread initially as a nutritional supplement, has been found to give very large, unexpected, increases in the loaf volume and organoleptical acceptability of wheat bread produced using flour samples with comparatively poor bread making properties. As a result progressive addition of pumpkin powder gave an initial rise and subsequent decrease in loaf volume. However no studies were found on the effect of pumpkin by-products on bread quality. 
The aim of the current study was to evaluate effect of fresh pumpkin pomace and pumpkin residue powder on wheat bread quality.

\section{MATERIALS AND METHODS}

\section{Ingredients}

The pumpkin cultivar 'Butternut Waltham' was used in the experiments for wheat bread enrichment. Thefruits of this cultivar tipically has weight around 1-2 kg, with light brown thin, smooth skin. This cultivar belongs to the genus of Cucurbita pepo, sort butter pumpkin Cucurbita moschata. Before further usage pumpkin samples were washed in warm water, dried, and cut into pieces.

For production of pumpkin juice and pomace a juice press Multipress compact MP75 (Braun GmbH, Germany) and a hand blender Multiquic 5 (Braun $\mathrm{GmbH}$, Germany) were used for obtaining more uniform residues. The obtained pumpkin pomace contained on average $81.6 \%$ moisture and $39.96 \mathrm{mg} / 100 \mathrm{~g}$ DW of carotenoids. All produced by-products were packaged in polypropylene containers ( 1 litre), frozen and stored in a freezer at $-18{ }^{\circ} \mathrm{C}$ until used.

Pumpkin powder was made from fresh pumpkin pomace. The pomace was dried in a convective drier UNB 200 with forced air circulation (Memmert $\mathrm{GmbH} \& \mathrm{Co.KG}$, Germany) at $70 \pm 2{ }^{\circ} \mathrm{C}$ temperature. Dried mass was ground in a laboratory mill Knifectec Mill 1095 (AB Foss Analytical, Sweden) obtaining pumpkin powder. Moisture content in produced powder was $4.9 \%$ and carotenoids content $-35.55 \mathrm{mg} / 100 \mathrm{~g}$ DW on average. Powder was vacuum packed in the polyethylene packages and stored in dark place at room temperature till further usage.

The following ingredients were used in the dough formulation: wheat flour type 550 (Dobeles dzirnavnieks, Latvia), dry baker's yeast (S.I.Lesaffre, France), salt (Artimsol, Ukraine), sugar (Dansukker, Nordic Sugar, Denmark), margarine Eve Baking (Bunge, Poland) and drinking water according to the Cabinet of Ministers of the $2003^{\text {rd }}$ of April $29^{\text {th }}$ rules No. 235 "Drinking water quality and the minimum safety requirements for the monitoring and control arrangements".

\section{Bread making}

Bread was made with traditional wheat bread making technology performing mixing of flour and aditives, kneading of dough in a planetary mixer Plutone LT10 (Minneapolis, Asia), proofing for $20 \mathrm{~min}$ at room temperature $\left(23 \pm 2{ }^{\circ} \mathrm{C}\right)$, dividing $(250 \pm 2 \mathrm{~g})$, forming, second proofing at $35 \pm 2{ }^{\circ} \mathrm{C}$ for 35 min, baking in a rotary oven S-400 (Sveba Dahlen AB, Sweden) with a proofing cabinet for $17 \pm 2 \mathrm{~min}$, at $200 \pm 10{ }^{\circ} \mathrm{C}$ temperature and cooling of 
bread till room temperature. Bread was made according to the recipes described in Table 1. Samples for further analyses were randomly selected from trhee batches.

Table 1. The recipes of wheat bread with pumpkin by-products calculated per $100 \mathrm{~kg}$ of flour

\begin{tabular}{|l|c|c|c|c|c|c|c|}
\hline $\begin{array}{c}\text { Sample } \\
\text { abbreviation }\end{array}$ & $\begin{array}{c}\text { Wheat } \\
\text { flour, type } \\
550(\mathrm{~kg})\end{array}$ & $\begin{array}{c}\text { Salt } \\
(\mathrm{kg})\end{array}$ & $\begin{array}{c}\text { Sugar } \\
(\mathrm{kg})\end{array}$ & $\begin{array}{c}\text { Yeast } \\
(\mathrm{kg})\end{array}$ & $\begin{array}{c}\text { Margarine } \\
(\mathrm{kg})\end{array}$ & $\begin{array}{c}\text { Pumpkin } \\
\text { addition } \\
(\mathrm{kg})\end{array}$ & Water (1) \\
\hline Control & 100 & 1.5 & 2 & 3 & 2 & - & 60 \\
\hline PP5 & 100 & 1.5 & 2 & 3 & 2 & 5 & 60 \\
\hline PP10 & 100 & 1.5 & 2 & 3 & 2 & 10 & 65 \\
\hline PP20 & 100 & 1.5 & 2 & 3 & 2 & 20 & 70 \\
\hline FPP10 & 100 & 1.5 & 2 & 3 & 2 & 10 & 50 \\
\hline FPP15 & 100 & 1.5 & 2 & 3 & 2 & 15 & 45 \\
\hline FPP20 & 100 & 1.5 & 2 & 3 & 2 & 20 & 40 \\
\hline FPP30 & 100 & 1.5 & 2 & 3 & 2 & 30 & 35 \\
\hline FPP40 & 100 & 1.5 & 2 & 3 & 2 & 40 & 30 \\
\hline FPP50 & 100 & 1.5 & 2 & 3 & 2 & 50 & 25 \\
\hline
\end{tabular}

* PP - pumpkin powder; FPP - fresh pumpkin pomace, number denotes per cent of addition, calculated form flour mass.

Moisture content, colour, and texture

Bread moisture content was determined according to AACC (2000) method no. 44-15A, using the balance Kern EW ( $\mathrm{d}=0.01 \mathrm{~g}$; Kern \& Sohn $\mathrm{GmbH}$, Germany) and the drying oven UNB 200 (Memmert GmbH \& Co.KG, Germany). Average values of three batches are reported.

Bread crumb colour was measured in CIE L*a*b* colour system using a colorimeter ColorTec PCM (Accuracy Microsensors Inc., USA). Colour of 5 random bread slices was measured and the mean values are reported for each sample. CIE $\mathrm{L}^{*} \mathrm{a} \mathrm{b}^{*}$ coordinates show the degree of lightness (L), the degree of redness $(+a)$, or greenness $(-a)$, and the degree of yellowness $(+b)$, or blueness $(-b)$, respectively.

For evaluation of colour change the total colour difference $\Delta \mathrm{E}^{*}$ was calculated between measurement in wheat bread and bread made with pumpkin addition according to equation (1).

$$
\Delta E^{*}=\sqrt{\left(L^{*}-L_{0}^{*}\right)^{2}+\left(a^{*}-a_{0}^{*}\right)^{2}+\left(b^{*}-b_{0}^{*}\right)^{2}},
$$

where: $L^{*}, a^{*}, b^{*} \quad$ - value measured in wheat bread sample;

$L^{*}{ }_{0}, a^{*}{ }_{0}, b^{*}{ }_{0} \quad-$ value measured in bread sample with pumpkin addition. 
Bread was sliced in the $1 \mathrm{~cm}$ thick slices for texture analysis on a texture analyser TA.HD.plus (Stable Micro Systems Ltd., UK). Texture analysis of the crumb was performed on three slices taken from the centre of each loaf. A $25 \mathrm{~mm}$ diameter cylindrical aluminium probe was used in bread crumb hardness measurement. Pre-test speed was set at $1 \mathrm{~mm} / \mathrm{s}$, test speed $10 \mathrm{~mm} / \mathrm{s}$, post test speed $-1 \mathrm{~mm} / \mathrm{s}$, trigger force $-0.04903 \mathrm{~N}$, the measurement target - distance $4 \mathrm{~mm}$. Maximum force was determined using the software Exponent. The average values of 10 measurements are reported.

\section{Carotenoids}

Carotenoids were analyzed by a spectrophotometric method (UV/VIS spectrophotometer, Jenway 6705, Bibby Scientific Ltd., UK), at $440 \mathrm{~nm}$ described by Kampuse et al. (2012). The content of carotenoids (mg/100 g) was calculated by equation (2):

$$
X=\frac{0.208 \times 25 \times K E}{36 \times a},
$$

where: 0.208 and 36 -coefficients for relationship between $\mathrm{K}_{2} \mathrm{Cr}_{2} \mathrm{O}_{7}$ and carotenoids;

$K E$ - carotene equivalent from graduation curve;

$a$ - sample weight, $\mathrm{g}$.

Sensory analysis of bread

Sensory evaluation was completed by 5 experts, experienced in bread making and bread sensory quality testing. Descriptive test was used for detection and description of bread of sensory properties quality. Descriptors for evaluation of bread sensory properties (appearance, bread crust, porosity, crumb elasticity, taste and aroma) were determined by consensus of all five experts. Each sensory property was evaluated in the range from 5 (very good quality) to 1 (unsatisfactory quality, serious defects). The sum of total scores (Table 2) for each bread sample is used to describe bread quality.

Table 2. Scores of descriptive tests for the evaluation of bread sensory quality

\begin{tabular}{|l|l|}
\hline \multicolumn{1}{|c|}{ Total scores } & \multicolumn{1}{c|}{ Quality evaluation } \\
\hline 25 & excellent quality \\
\hline $20-24$ & good quality \\
\hline $14-19$ & average quality \\
\hline less than 14 & unsatisfactory quality \\
\hline
\end{tabular}

\section{Data analysis}

The results (mean, standard deviation, $P$ value) were processed by mathematical and statistical methods by Microsoft Office Excel 2007; significance was defined at $P<0.05$. 


\section{RESULTS AND DISCUSSIONS}

The moisture content of bread with dried pumpkin by-products powder was from $40.69 \%$ for control sample till $41.77 \%$ to sample with $20 \%$ of incorporated pumpkin powder. But the moisture content of bread with incorporated frozen pumpkin pomace was from $40.32 \%$ for sample with $15 \%$ of pumpkin pomace till $43.07 \%$ for sample with $20 \%$ of pumpkin pomace. It means that the moisture content of all samples conforms to the quality requirements of $45 \%$ as maximaly allowed moisture content for wheat bread. The observed colour values for bread with different ratio of added pumpkin processing by-products are shown in Table 3 and the values are comparable with those reported by Rakcejeva et al. (2011). As a result of adding pumpkin by-products the bread yellowness $\left(+b^{*}\right.$ value) increased. Mostly, the attractive orange/yellow colour of pumpkin is attributed to the presence of lutein and $\beta$-carotene (Ahmed et al., 2014). Generally, the increase in the added amount caused more intense colour $b^{*}$ values and decrease of $L^{*}$ values, making bread colour darker.

Table 3. Colour of bread with pumpkin by-products

\begin{tabular}{|l|c|c|c|}
\hline \multicolumn{1}{|c|}{ Sample } & $\mathbf{L}^{*}$ & $\mathbf{a}^{*}$ & $\mathbf{b}^{*}$ \\
\hline Control & $75.52 \pm 0.61$ & $-4.41 \pm 0.42$ & $16.90 \pm 0.48$ \\
\hline PP5 & $73.14 \pm 0.55$ & $-5.46 \pm 0.55$ & $35.56 \pm 0.34$ \\
\hline PP10 & $71.24 \pm 0.51$ & $-4.53 \pm 0.60$ & $42.24 \pm 0.65$ \\
\hline PP20 & $68.18 \pm 0.46$ & $-3.41 \pm 0.62$ & $50.75 \pm 0.41$ \\
\hline FPP10 & $74.13 \pm 2.97$ & $-4.37 \pm 0.41$ & $22.89 \pm 0.97$ \\
\hline FPP15 & $72.80 \pm 0.50$ & $-4.93 \pm 0.51$ & $26.82 \pm 0.46$ \\
\hline FPP20 & $72.94 \pm 2.71$ & $-4.65 \pm 0.46$ & $27.48 \pm 0.42$ \\
\hline FPP30 & $73.56 \pm 0.37$ & $-4.23 \pm 0.24$ & $29.14 \pm 0.58$ \\
\hline FPP40 & $73.51 \pm 0.29$ & $-4.21 \pm 0.42$ & $33.82 \pm 0.64$ \\
\hline FPP50 & $74.05 \pm 0.45$ & $-3.78 \pm 0.25$ & $36.20 \pm 0.57$ \\
\hline
\end{tabular}

Among the bread samples, the values of the yellowness parameter $b^{*}$ ranged from $35.56 \pm 0.34$ in the sample containing $5 \%$ pumpkin powder to $50.75 \pm 0.41$ in the sample baked with $20 \%$ pumpkin powder addition. Slightly lower values were measured in the samples made with pumpkin pomace which yet were remarkably higher as compared to the control sample. The total colour difference between bread made with pumpkin by-product additions and wheat bread calculated by means of Eq. (1). are presented in Figure 1 . 


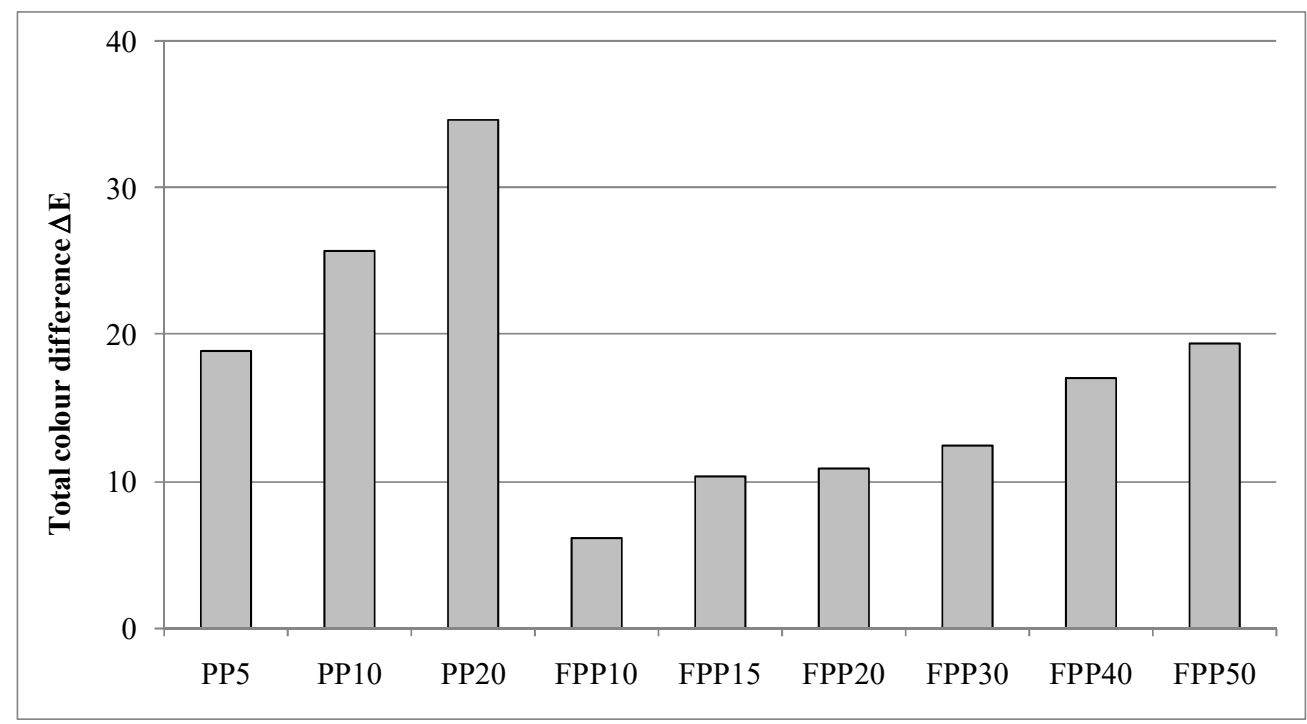

Figure 1. Total colour difference of bread with pumpkin addition ( $\mathrm{PP}$ - pumpkin powder; FPP - fresh pumpkin pomace) compared to control sample (wheat bread without pumpkin addition).

The results indicate that total difference in colour depends on the pumpkin by-products ratio in the bread. In all cases, $\Delta \mathrm{E}^{*}$ increased with addition concetration. Higher $\Delta \mathrm{E}^{*}$ values were observed in products with pumpkin powder probably due to higher dry matter content in powder, thus adding more carotenoids which are considered to be pigments of yellow/orange colour.

Bread crumb texture results (Figure 2) indicate that bread hardness is affected $(\mathrm{P}<0.05)$ by pumpkin by-products.

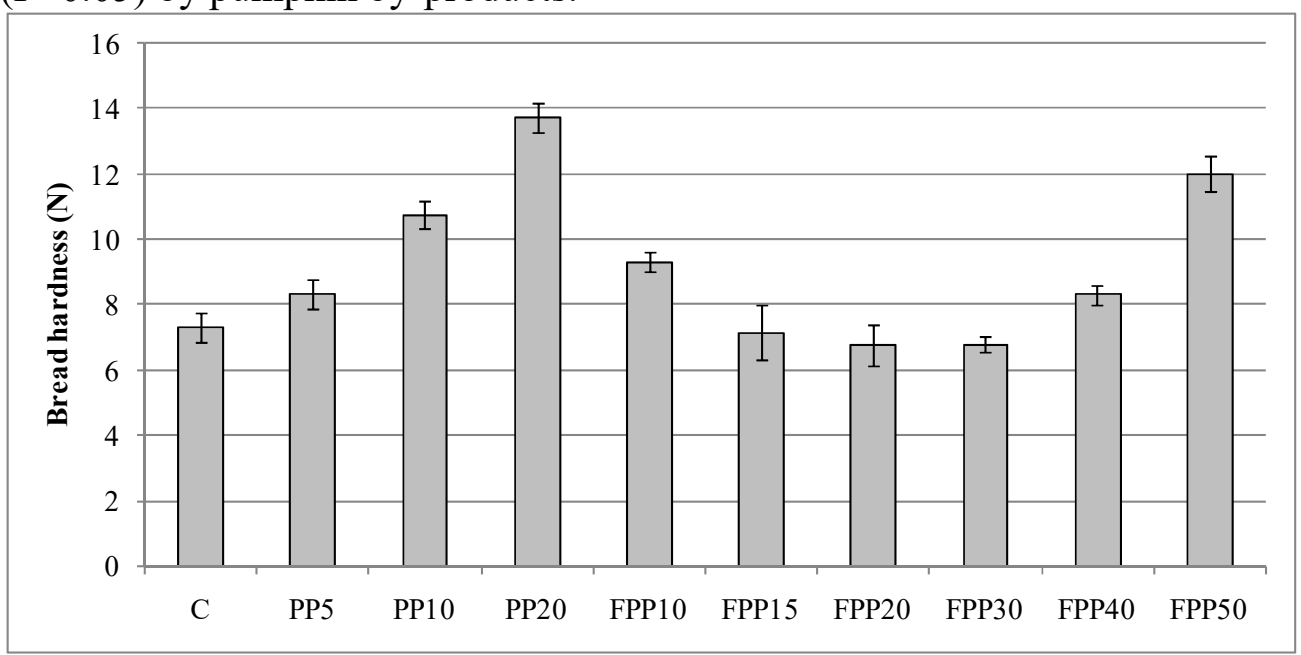

Figure 2. The hardness of bread with pumpkin addition: ( $\mathrm{PP}$ - pumpkin powder; FPP - fresh pumpkin pomace) and control sample (wheat bread). 
The increased amount of pumpkin powder caused increase in bread crumb hardness. However in case of pumpkin pomace initially bread crumb hardness decreased, but high amounts of pomace $(40 \%$ and $50 \%)$ increased the hardness.

Sensory evaluation (appearance; crust; porosity; crumb elasticity; taste, and aroma) of wheat bread with pumpkin revealed very high expert scores (Table 4).

Table 4. Sensory quality of bread with pumpkin by-products

\begin{tabular}{|c|c|c|c|c|c|c|}
\hline \multirow[b]{2}{*}{ Sample } & \multicolumn{5}{|c|}{ Sensory qualities } & \multirow[b]{2}{*}{$\begin{array}{c}\text { Total } \\
\text { scores }\end{array}$} \\
\hline & 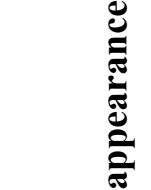 & $\overline{\tilde{\omega}}$ & 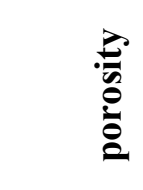 & 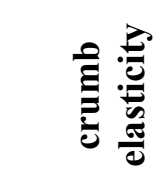 & 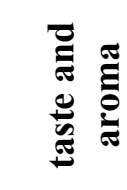 & \\
\hline $\mathrm{C}$ & 5 & 5 & 5 & 5 & 5 & 25 \\
\hline PP5 & 5 & 5 & 5 & 5 & 4 & 24 \\
\hline PP10 & 5 & 5 & 5 & 5 & 5 & 25 \\
\hline PP20 & 5 & 5 & 4 & 5 & 3 & 22 \\
\hline FPP10 & 5 & 5 & 5 & 5 & 4 & 24 \\
\hline FPP15 & 5 & 5 & 5 & 5 & 4 & 24 \\
\hline FPP20 & 5 & 5 & 5 & 5 & 5 & 25 \\
\hline FPP30 & 5 & 5 & 4 & 4 & 5 & 23 \\
\hline FPP40 & 5 & 5 & 4 & 2 & 5 & 21 \\
\hline FPP50 & 5 & 5 & 3 & 2 & 4 & 19 \\
\hline
\end{tabular}

In sensory evaluation, the bread with 5\% pumpkin powder scored 4 points in bread taste and aroma because it did not have at all taste and aroma of addition and it was considered as a small defect. The same evaluation got breads with 10 and $15 \%$ pumpkin pomace. Nevertheless product was rated of good quality. A $20 \%$ pumpkin powder addition is considered being too high because of reduced porosity and taste along with aftertaste was scored as too sweet (bread quality - good). Sensory evaluation revealed that sample with $10 \%$ pumpkin powder and the sample with $20 \%$ pumpkin pomace had excellent quality. Generally, it can be seen that powder addition up to $20 \%$ and pomace addition up to $50 \%$ do not affect $(\mathrm{P}>0.05)$ wheat bread appearance and crust properties. However, higher amounts of pumpkin pomace reduce bread porosity and make bread crumb sticky upon chewing. Pomace addition in amount of 40-50\% from flour mass caused uneven and big pores, bread crumb becomes sticky (bread quality from good quality (FPP40) to average(FPP50)). In bread with $50 \%$ pomace small, dense pores were formed along bread crust. 
The initial increase of pumpkin addition indicated increase in loaf volume, which started to decrease at higher amounts $(20 \%$ for powder and $40-50 \%$ for pomace) and it corresponds to the lower sensory evaluation and increased hardness. In the bread sample with $30 \%$ pomace uneven large pores can be seen at the top part of the loaf, which indicates to ongoing fermentation process at the beginning of baking. Final bread volume depends on dough expansion during fermentation and baking, and ability of the matrix to stabilize the retained gas. Thus it can be concluded that in case if pomace addition is above $30 \%$, longer proofing time is required because pumpkin slows down dough fermentation.

Taking into account sensory attributes, bread crumb porosity, elasticity and colour it can be concluded that $10 \%$ of powder and $20 \%$ of pomace may be considered as the optimum value. Above these bread porosity increased, pores were unevenly distributed in the crumb, bread crumb was darker and the taste was too sweet.

Pumpkin is rich in carotene, vitamins, minerals, pectin and dietary fibre (Djutin, 1991). Hence, supplementation of pumpkin flour would improve the nutritional quality of bread (Ptitchkina et al., 1998). In the experiments with pumpkin pomace and powder total carotenoids content in wheat bread significantly $(\mathrm{P}<0.001)$ increased by adding pumpkin by-products. The carotenoids content in the sample with $20 \%$ pumpkin residue powder was $2.21 \mathrm{mg} / 100 \mathrm{~g} \mathrm{DW}$, in the sample with $50 \%$ pumpkin pomace it was $0.85 \mathrm{mg} / 100 \mathrm{~g}$ DW, which was significantly higher $(\mathrm{P}<0.001)$ than its content in control sample - $0.07 \mathrm{mg} / 100 \mathrm{~g}$ DW (Fig. 3).

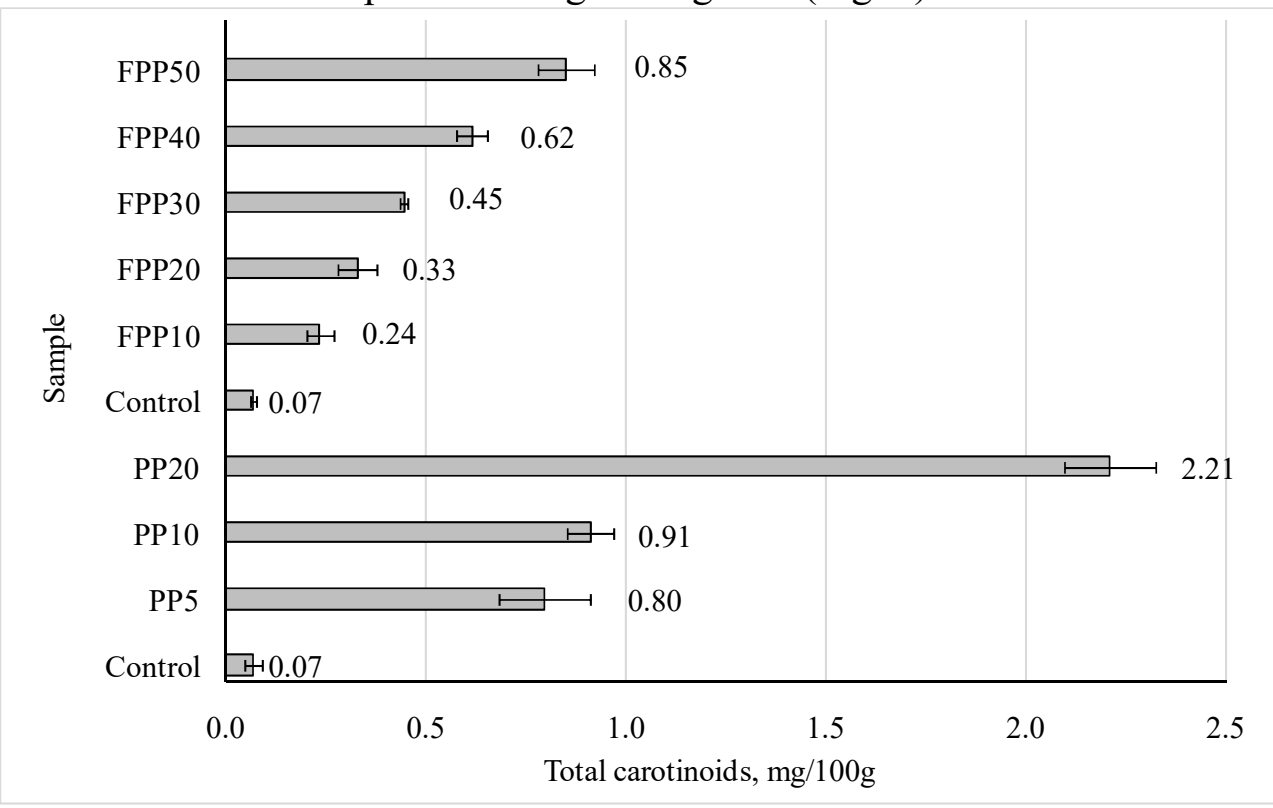

Figure 3. Total carotenoids in wheat bread with pumpkin pomace and powder. 
Generally, the relationship between carotenoid content in bread and its yellowness was observed and is presented in Figure 4. Carotenoids are pigments that derive from isoprene and that give flowers, leaves, and fruits a colouration that ranges from yellow to red (Oliver \& Palou, 2000).

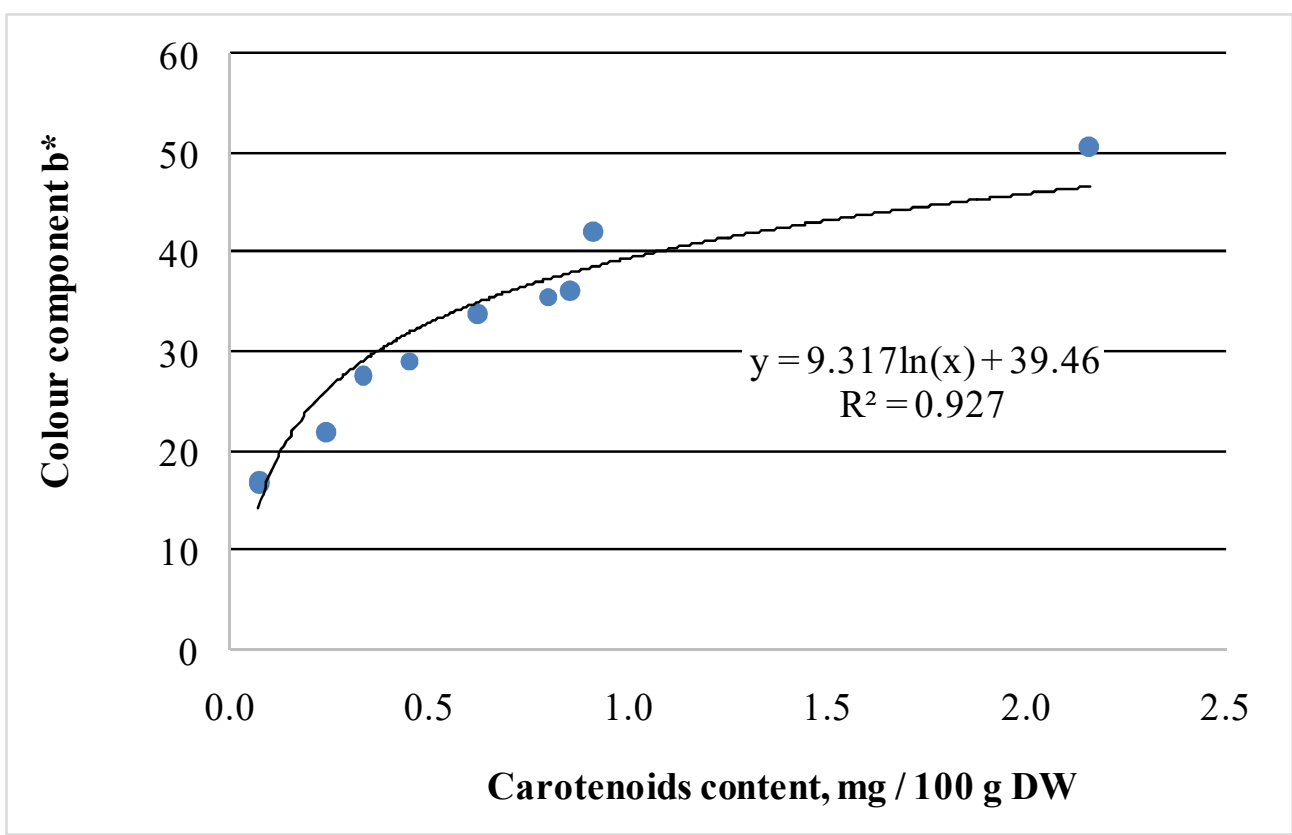

Figure 4. Correlation between the carotenoids content and colour component $b *$ value.

Being a good source of carotenoids pumpkin proves to increase yellowness value in bread colour.

\section{CONCLUSIONS}

It is recommended to add $10 \%$ of pumpkin powder and no more than $20 \%$ of pumpkin pomace to dough for production of high quality wheat bread with pumpkin by-product addition. The addition of pumpkin by-products increased the content of carotenoids in wheat bread from 5 times by adding pomace till 13 times by adding pumpkin powder, if is used optimum amount.

\section{ACKNOWLEDGEMENTS}

National Research Programme "Sustainable agricultural resources of high quality and healthy food production Latvian (AgroBioRes)" (2014-2017). Project No. 4 „Sustainable use of local agricultural resources for development of quality and healthy food product development (FOOD)". 


\section{REFERENCES}

1. AACC (2000) Approved methods of the American Association of Cereal Chemists $\left(10^{\text {th }}\right.$ ed.). Saint Paul, Minnesota.

2. Ahmed, J., Al-Foudari, M., Al-Salman, F., \& Almusallam, A. S. (2014). Effect of particle size and temperature on rheological, thermal, and structural properties of pumpkin flour dispersion. Journal of Food Engineering, 124, pp. 43-53. dx.doi.org/10.1016/j.jfoodeng.2013.09.030

3. Azizah, A. H., Wee, K. C., Azizah, O., \& Azizah, M. (2009). Effect of boiling and stir frying on total phenolics, carotenoids and radical scavenging activity of pumpkin (Cucurbita moschata). International Food Research Journal, 16, 45-51.

4. Carvalho, de L. M. J., Gomes, P. B., Oliveira Godoy, de R. L., Pacheco, S., Monte, do P. H. F., Carvalho, de J. L. V., Nutti, M. R., Lima Neves, A. C., Rodrigues Alves Vieira, A. C., \& Ramos, S. R. R. (2012). Total carotenoid content, $\alpha$-carotene and $\beta$-carotene, of landrace pumpkins (Cucurbita moschata Duch): A preliminary study. Food Research International, 47, pp. 337-340. doi:10.1016/j.foodres.2011.07.040.

5. Coelho, M.S. \& Salas-Mellado, M. M. (2015). Effects of substituting chia (Salvia hispanica L.) flour or seeds for wheat flour on the quality of the bread. LWT - Food Science and Technology, 60(2), 729-736. dx.doi.org/10.1016/j.lwt.2014.10.033

6. Djutin, K.E. 1991. Pumpkin: nutritional properties. Potatoes and Vegetables, 3: 25-26 (in Russian).

7. Gailite, I., Strautniece, E., \& Seglina, D. (2008). Sensory properties of wheat bread with raspberry marc. In: Conference proceedings of $3^{\text {rd }}$ Baltic Conference on Food Science and Technology FOODBALT-2008. Jelgava, LLU, 126-129.

8. Gedrovica, I., \& Karklina, D. (2011). Influence of Jerusalem artichoke powder on dough rheological properties. In: Proceedings of 6th Baltic Conference on Food Science and Technology "Innovations for Food Science and Production" FOODBALT-2011, May 5-6, 2011, Jelgava: LLU, 7-12.

9. González, E., Montenegro, M. A., \& Nazareno, M. A. (2001). Carotenoid composition and vitamin A value of an Argentinian squash (Cucurbita moschata). Archivos Latinoamericanos de Nutrición, 51(4), 395-399 Retrieved from: http://www.scielo.org.ve/scielophp?script=sci arttext\&pid=S000406222001000400012\&lng=es\&nrm=iso

10. Kampuse, S., Berna, E., Muizniece-Brasava, S., Dukalska, L., Murniece, I., Sabovics, M., Kruma, Z., Ruse, K., Sarvi, S., \& Kampuss, K. (2012). Influence of Active Packaging on the Quality of Pumpkin - Rowanberry 
Marmalade Candies. World Academy of Science, Engineering and Technology, 6, 1341-1349.

11. Kandlakunta, B., Rajendran, A., \& Thingnganing, L. (2008). Carotene content of some common (cereals, pulses, vegetables, sp ices and condiments) and unconventional sources of plant origin. Food Chemistry, 106, 85-89. doi:10.1016/j.foodchem.2007.05.071

12. Kuhlmann, H. K., Koetter, U., \&Theurer, C. (1999). Sterol contents in medicinalpumpkin (Cucurbita pep oconvar. citrullinina var. styriaca). Acta Horticulturae, 492, 175-178.

13. Lee, C. H., Cho, J. K., Lee, S. J., Koh, W., Park, W., \& Kim, C. H. (2002). Enhancing $\beta$-carotene content in Asian noodles by adding pumpkin powder. Cereal Chemistry, 79(4), 593-595. dx.doi.org/10.1094/CCHEM.2002.79.4.593

14. Noelia, J.-V., Roberto, M.-J. M., Jesús, de Z.-M. J., \& Alberto, G.-I. J. (2011). Physicochemical, technological properties, and health-benefits of Cucurbita moschata Duchense vs. Cehualca: A Review. Food Research International 44, 2587-2593. doi:10.1016/j.foodres.2011.04.039

15. Noseworthy, J., \& Loy, B. (2008). Improving eating quality and carotenoid content of squash. In M. Pitrat (Ed.), Proceedings of the IXth EUCARPIA meeting on genetics and breeding of Cucurbitaceae, INRA, Avignon (France), May 21-24th, 521-528.

16. Oliver, J., \& Palou, A. (2000). Chromatographic determination of carotenoids in foods. Journal of Chromatography A, 881, 543-555.

17. Ptitchkina, N.M., Novokreschonova, L.V., Piskunova, G.V., \& Morris E.R. (1998). Large enhancements in loaf volume and organoleptic acceptability of wheat bread by small additions of pumpkin powder: possible role of acetylated pectin in stabilizing gas-cell structure, Journal of Food Hydrocolloids, 12(3), 333-337.

18. Rakcejeva, T., Galoburda, R., Cude, L., \& Strautniece, E. (2011). Use of dried pumpkins in wheat bread production. 11th International Congress on Engineering and Food (ICEF11). Procedia Food Science, 1, 441447.doi:10.1016/j.profoo.2011.09.068

19. Ермакова, А.И. (1987). Методы биохимического исследования растений. Под ред. А.И.Ермакова, Ленинград, ВО Агропромиздат, 107-108. (in Russian) 